\title{
Mollusc Communitiess at Coastal Kemantren, Paciran, Lamongan
}

\author{
Marita Ika Joesidawati* \\ Universitas PGRI Ronggolawe, Indonesia
}

Submission: November 30, 2017; Published: February 12, 2018

*Corresponding author: Marita Ika Joesidawati, Fakultas Fisheries and Marine Science, Universitas PGRI Ronggolawe, Tuban, Indonesia, Email: rita_joes@yahoo.com

\begin{abstract}
Research was to obtain mollusc densities, for classification quadrant station using mollusc communiาties at coastal Kemantren, Paciran district, Lamongan regengcy, East Java Province from November to December 2014, used descriptive method; data was collected from 3 stations was Station 1 located at mouth of river, Station II. located at settlement of inhabitant, and Station III located at mangrove. The lowest density of mollusc (1 individu) for instaned Nassarius arcularius at mouth of river. The highest density of mollusc (27 individu) at species Cerithiopsis emersoni at mouth river, meanwhile data analysed used cluster analysis SPSS program classified coastal (quadrant station) Kemantren into 3 of cluster. Cluster I located at mouth river and near the settlement, cluster II located near the settlement and mangrove forest, and cluster III located only at mangrove forest. Based the research result, it is recommended to sample in the various of substrat.
\end{abstract}

Keywords: Classification; Station; Cluster

\section{Preliminary}

Mollusca are found in Indonesian waters mainly of sea grass and coral averages with sand substrate, muddy sand and dead coral fractures. There are several types of mollusks that have important economic value that can be used as food, craft and industry [1]. According to Arfiati [2], many types of shellfish have economic value because they are human food ingredients. Kemantren village has a coastal area with a length of approximately $695 \mathrm{~m}$, is an open coastal area. The people of Kemantren village use mollusca to consume. Some kinds of moluslka are consumed and have selling value, among others Gafrarium tumidum, Tagelus divisus, Anadara sp, Cerilhiopsis matara, Cerithiopsis emersoni and Nerita sp.

With this reason it is very interesting to study especially the community of organisms that live in tidal areas, especially from the type of mollusca that have a slow movement along with several environmental factors that support their lives in the coastal area. The purpose of this study is to obtain density, cluster sites (stations and quadrants) by using the mollusc community from coastal waters of Kemantren village. The research was conducted in coastal waters of Kemantren village, Paciran sub-district, Lamongan district, East Java province in November-December 2014.

\section{Methodology Research}

\section{Determination of observation station}

The station taken in this research there are 3 locations, namely as follows: Station I: near the mouth of the river; Station II: near settlement; Station III: near the coastal mangrove forest of Kemantren Village. Before determining the number of quadrants to be taken then the first thing to do is measure the width of the tides, where the tidal width is found to be approximately $30 \mathrm{~m}$. After the width of the tide is known then from each station from land to sea transect line made $30 \mathrm{~m}$ long. Each $1 \mathrm{~m}$, the substrate was taken, to obtain the number of substrate as many as 30 samples in each transect. The substrate is then analyzed to determine the type of substrate.

Based on 90 substrate analysis results from 90 quadrants, then the selected 15 quadrants were chosen based on different types of substrates to be observed and to identify the samples of mollusca taken in a quadrant. Station I of 7 quadrants (K2, K5, K8, $\mathrm{K} 11, \mathrm{~K} 15, \mathrm{~K} 23$, and K27), station II of 4 quadrants (K2, K8, K15, and K29), while station III 4 quadrants (K1, K5, K14 and K24). All quadrants are selected based on the substrate type change. Mollusc sampling and water quality physics (temperature) as well as chemistry (pH, salinity, and organic matter) are carried 
out when the water moves down. At each station 1 transect line along $30 \mathrm{~m}$ is drawn perpendicular to the coastline toward the sea (lowest tide). In the $1^{\text {st }}$ transect a quadrant is made, the $2^{\text {nd }}$ transect is made into 4 kuadran and the $3^{\text {rd }}$ transect is made up of 4 quadrants, each of which is a quadrant of $\mathrm{lm} \mathrm{x} \mathrm{lm}$. Sampling is done only once, this is because one capture represents each station.

The collected live mollusca are preserved with an alcohol solution of $70 \%$ [1]. All samples that have been collected are sorted by their species and counted in number, then identified by Dharma [3], Roberts et al. [4], Morris [5,6]. To know the density and frequency of attendance, a measurement method is based on Soegianto [7].

\section{Data analysis}

The mollusca that have been identified are then analyzed using cluster analysis, which classifies site (site) by using mollusca based on similarity characteristic among the research objects. In this study cluster is used to group the location by using the mollusk that has been found [8]. The purpose of the cluster analysis is to group m samples into the same group $g$ gene, where $g$ is unknown, gm [9]. In this study, the amount of $g$ $=3$, because the number of $\mathrm{m}$ (quadrant) $=15$, the determination of 3 is based on the type of substrate, found there are three kinds of sand, sand and clay sand cluster cluster images can be seen in Appendix.

\section{Results and Discussion}

\section{Station description}

Coastal Paciran especially in the area of Kemantren Village is an open coast with a coastal length of approximately $0.695 \mathrm{~km}$. This coastal area is utilized by the people of Kemantren Village as the source of the fulfillment of the primarily animal food needs, namely fish, crab and mollus ka. The Kemantren Coastal area is also used as a household garbage disposal (plastic, paper, or used food). Besides, the residents also use the beach as a place to defecate, sailboats with outboard engines are also moored in the coastal area of Kemantren besides that there is also stone mining in some parts of coastal Kemantren.

\section{Station I}

Station I is located in front of the river estuary, the river is long dead, near the settlement of population, so as well as a place to belay sailing and oil extraction, household waste disposal (plastic, paper, and food) and was defecating. On the shores of the coast also contain vegetation such as waru, and sea kangkung. This station is a sloping area, in addition it is close to the rocky area.

\section{Station II}

Station Ii, located about $100 \mathrm{~m}$ from Station I to the East, lies near the population settlement. Utilized by residents as household garbage dumps (plastic, paper, food) and defecating.
This area has a bamboo tree, from a nearby cemetery on the beach. Substrate contents include a type of rocky substrate, which is visible when the water moves down.

\section{Station III}

Station III is located about $400 \mathrm{~m}$ from Station II to the East, located in front of mangroves or mangroves, and there are other plants such as waru and bamboo trees. This station is utilized by the population as a place to belay the sailboat, so that in this area can be found waste of ex-oil used oil waste that has seeped into substract, which can be seen when the sampling is done by digging. In addition there is also household waste (paper and plastic) disposed of residents, and also this location is used as a place to defecate. This location is very gentle and rocky visible at the time the water moves down.

\section{Ecological facts of coastal waters village Kemantren}

Substrate: The results of substrate analysis at stations I and II are sandy, sandy clay, and sandy clay, and sandy type at station III (see Table 1). According to Romimohtarto \& Juwana [10] the substrate type of aquatic base also affects the types of marine animals that can live on or in the ocean floor. Meanwhile, according to Nybakken [11] in addition to the rocky mollusks can also live on sandy substrates such as large shells such as Tivela stultorum, Pismo shells, the small of the genus Donax, and razor shells of the genus Siliqua; on a muddy substrate of bivalve mollusks can also live, moon snails (Polinices, Natica, Glycera). The coastal waters of Kemantren are a suitable area as a place of life for mollusca.

Temperature: The temperature range obtained during the measurement is in the range $27-33^{\circ} \mathrm{C}$ (see Table 1 ). The lowest temperature $\left(27{ }^{\circ} \mathrm{C}\right)$ is obtained at station II K29. Station II is an area in front of the residential area, which contains bamboo trees and near the cemetery. Low temperature is caused because the location is near the cemetery of many trees (frangipani trees) and bamboo pole, so this area becomes shade, the other way the sampling is done in the morning. The highest temperature (33 ${ }^{\circ} \mathrm{C}$ ) is obtained at station III K5. Station III is an area in front of mangroves, on the edge of the waters covered with mangrove trees. High temperatures are due to K5 rather far from the waters edge so far from the shade of the trees, in addition the sampling time is late in the day where the water temperature begins to warm.

According to Dahuri et al. [12] the temperature of awater is influenced by solar radiation, sun position, geographical position, seasons, cloud conditions, and processes between water and air, such as overhead, evaporation, and wind gusts. According to Salamet [13], the mollusca on the coast of Pesisir Village, Probolinggo regency, East Java Province can live in the temperature range $27-30{ }^{\circ} \mathrm{C}$. The results of temperature measurements in the coastal waters of Kemantren Village indicate that they are still within the supporting range for the life of the mollusc community. 
Table 1: Environmental Factors of Coastal Waters of Kemantren Village.

\begin{tabular}{|c|c|c|c|c|c|c|c|}
\hline \multirow[b]{2}{*}{ Station } & \multirow[b]{2}{*}{ Kuadran } & \multirow[b]{2}{*}{ Code Station } & \multicolumn{5}{|c|}{ Ecological Facts } \\
\hline & & & Substrate & $\begin{array}{c}\text { Temperature } \\
\left({ }^{\circ} \mathrm{C}\right)\end{array}$ & pH & Salinity (o/oo) & $\begin{array}{c}\text { Soil Organic } \\
\text { Materials (\%) }\end{array}$ \\
\hline \multirow{3}{*}{ I } & $\mathrm{K}_{2}$ & $1-5$ & 1 & 28 & 8 & 36 & 0,11 \\
\hline & $\mathrm{K}_{5}$ & $6-11$ & 2 & 28 & 8 & 35 & 0,21 \\
\hline & $\mathrm{K}_{8}$ & $12-16$ & 1 & 28 & 8 & 33 & 0,21 \\
\hline \multirow{4}{*}{ I } & $\mathrm{K}_{11}$ & $17-21$ & 2 & 29 & 8 & 35 & 0,11 \\
\hline & $\mathrm{K}_{15}$ & $22-25$ & 3 & 29 & 8 & 35 & 0,11 \\
\hline & $\mathrm{K}_{23}$ & $26-27$ & 2 & 30 & 8 & 35 & 0,43 \\
\hline & $\mathrm{K}_{27}$ & $28-29$ & 2 & 31 & 8 & 37 & 0,21 \\
\hline \multirow{3}{*}{ II } & $\mathrm{K}_{2}$ & $30-31$ & 2 & 28 & 8 & 31 & 0,11 \\
\hline & $\mathrm{K}_{8}$ & $32-35$ & 3 & 30 & 8 & 30 & 0,21 \\
\hline & $\mathrm{K}_{15}$ & $36-39$ & 1 & 29 & 8 & 32 & 0,53 \\
\hline II & $\mathrm{K}_{29}$ & $40-44$ & 1 & 27 & 8 & 30 & 0,53 \\
\hline III & $\mathrm{K}_{1}$ & $45-54$ & 1 & 32 & 8 & 30 & 0,11 \\
\hline \multirow{3}{*}{ III } & $\mathrm{K}_{5}$ & $55-63$ & 1 & 33 & 8 & 30 & 0,21 \\
\hline & $\mathrm{K}_{14}$ & $64-69$ & 1 & 32 & 8 & 30 & 0,43 \\
\hline & $\mathrm{K}_{24}$ & $70-78$ & 1 & 28 & 8 & 25 & 0,43 \\
\hline
\end{tabular}

1: Sandy, 2: Sandy clay, 3: Sandy clay.

pH: pH obtained during the measurement is 8 (Table 1). All stations of stations I, II and III have the same $\mathrm{pH}$ of $8 . \mathrm{pH}$ is at number 8 means alkaline waters, disebabkan because the measuring area is a coastal waters area. According to Hellawel [14], $\mathrm{pH}$ values indicate the degree of acidity or alkalinity of a water. The neutral $\mathrm{pH}$ value is 6-7 and in this range the physiological function runs primarily primarily related to respiration. This means that $\mathrm{pH}$ affects membrane permeability. According to Nybakken [11] the seawater is slightly alkaline, usually the $\mathrm{pH}$ varies from 7.5 to 8.4. $\mathrm{pH}$ of Kemantren Village waters is still at a good rate for the life of mollusca.

Salinity: The salinity obtained during the measurement is about $25-37 \%$. (Table 1 ). The low salinity (25\%) was obtained at station III K24. Station III is an area in front of mangrove and there is fresh water flow. Nevertheless still can be inhabited mollusca. The highest salinity (37\%) was obtained at station I K27 (Table 1). Station I is the area in front of the river estuary which overgrown with sea kangkung and also there is waru tree. The high salinity (37\%) was due to sampling conducted during the day, at which time the sunny weather of the evaporation process took place and the water receded. According to Nybakken [11] salinity increases can occur if the evaporation is very high during the day. In general, the salinity of the surface of Indonesian waters averages between $32-37 \%$. Salinity in coastal waters Kemantren village is still in the normal range for the life of mollusca.

Soil organic materials: The level of organic material obtained during the measurement is in the range of $0.11-0.53 \%$ (Table $1)$. The lowest organic material $(0.11 \%)$ was obtained at station I K2, K11 and K15, station II K2 and station III K1 (Table 1),
Station I is located in front of river mouth, station II is in front of residential area and station III is in front of mangroves. Low organic matter $(0.11 \%)$ is caused by the type of substrate containing sand, so the organic material is easily washed when tidal, in addition the location directly faces the high seas. According to Dahuri et al. [12] coarse particles (sand) cause only a small part of the surface to absorb both dissolved and very small organic matter. Organic matter is also not available for bacteria. Mollusks in the coastal waters of Kemantren village are still able to live at a $0.11 \%$ organic matter content, and it is thought that the mollusks in the daerah are fed by filtering plankton from seawater or inhaling the sediment of organic matter from the surface. The highest organic material (0.53\%) was obtained at station II K15 and K29 (Table 1). Station II is an area in front of residential settlements, which at the time of the research there is a lot of garbage disposal, and large water waste but the type of sandy substrate. The high organic matter at $0.53 \%$ in this area is suspected because of the input of the waste that has been disposed of by the population.

Composition of mollusca: Based on the research results obtained 3 kelas the class Gastropoda, Pelecypoda and Polyplachopora, 3 orders, 25 species and 238 taxa. The lowest no (3) at station code 30-31 (station II, K2) (Table 1 \& Figure 1 ). The number of domestic taxes (3) is due to the type of clayed substrate (Table 1) and station II is located in front of the settlement, and in addition the location of $\mathrm{K} 2$ is on the edge of the waters, where on the edge of the waters there is much discarded waste by settlers. Nybakken [11] in addition to the rocky areas of mollusks can also live on sandy substrates, and muddy substrates. The number of low taxa (3) is presumed to 
be a disturbance of the waters edge caused by the activity of the population, so that the mollusc community at that point is low.

The number of high taxa (34) in the station code 45-54 (SIIIK,) is due to the type of sandy substrate (Table 1 \& Figure 1), in addition it is the area in front of the mangroves that are far from the settlements, and a lot of mangrove leaves. According to Snedaker et al. in Dahuri et al. [12] mangrove forests has important significance because it provides a contribution of organic material to the surrounding waters. Locations in front of the mangrove cause in this area are found many different types of mollusca. The lowest number of individuals (1 individual), among others, of the Nassartus arcularius species, found in station I (K) station code 12-16 with sandy substrates, Urosalpinx perrugate species at station II (K15) 36-39 de With sandy and sandy substrate types and Nassarius viticusis species at station III (K1) station code 55-63 with sandy substrate type (Table 1). This is in accordance with the opinion of Roberts et al. [4] mollusca from the Nassariidae family and Muricidae can be found in sandy and sandy climates. Therefore station III is a suitable location for the life of Nassarius viticusis.

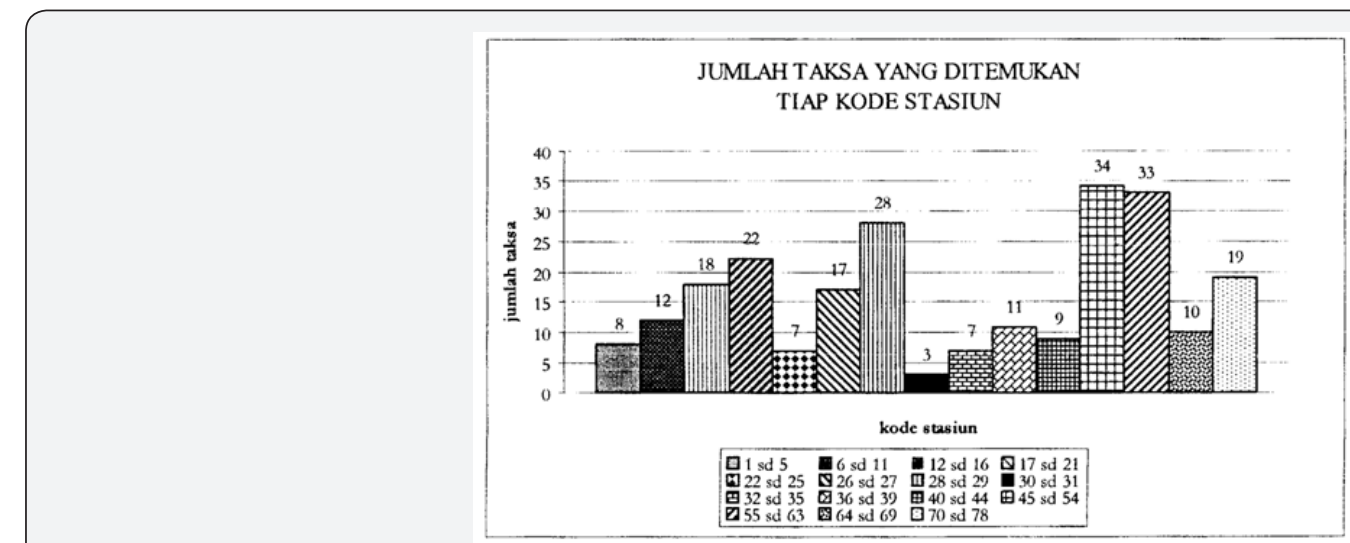

Figure 1: Number of taxa found every station code.

Station I is near the mouth of the river, and station II is in front of the settlement, utilized as a waste disposal place, so the mollusca are disturbed, so the number of individuals is found only slightly. While the mollusca at station III located in the mangrove where the area is used as a place of belaying of the ship and also there is oil waste of the ship, therefore with the oil waste suspected mollusca disturbed.

The largest number of individuals found was Cerithiopsis (27 individuals), which was found in the area near the river estuary (station I, K27, station code 28-29), with a clay sand substrate condition (Table 1). Cerithiopsis emeionsi are found in this location, the substrate is sandy clay, and is clean of garbage. According to Severns et al. [15] a small portion of the species of the Cerithiidae family prefer to live in sandy and sandy areas. Molluscs are still able to live in this area, one of them is from the species of Cerithiopsis emersoni.

\section{Density and frequency of relative presence of mollusca}

\section{Station I}

Based on the data analysis, the species of emery erythiopsis emersoni has the highest density of $48 \mathrm{ind} / 7 \mathrm{~m}^{2}$, this means that in the area of $7 \mathrm{~m}^{2}$ can be obtained 48 individuals Cerithiopsis emersoni with relative attendance frequency $41.7 \%$ (Table 2), which means the possibility of finding emerythis emersoni from all constants found is $41.7 \%$. The station is located in front of the river estuary with environmental factors such as sandy sand substrate, sandy clay and sandy clay, temperature $28-29{ }^{\circ} \mathrm{C}, \mathrm{pH}$ 8 , salinity $33-37 \%$, and organic material content ranges from 0,11-0.43\%. At this station Cerithiopsis emerionsi are found abundantly above ground level, and are increasingly found in areas far from waters edge. Roberts et al. [4] states that the family of Cerithiidae found in tidal areas is mostly found in sandy and sandy areas. Cerithiopsis emersoni utilized by coastal people of Kemantren for consumption. Therefore, Cerithiopsis emersoni which is commonly found in this area can be produced through cultivation, so its preservation is maintained.

The lowest density, among others, is found in Planaxis sulcatus (1ind $/ 7 \mathrm{~m} 2$ ), this means that in an area of $7 \mathrm{ml}$ one can obtain 1 individual Planaxis sulcatus with a relative presence frequency at Planaxis sulcatus of $0.8 \%$, this means that the possibility of finding Planaxis sulcatus from all constants found in this area is $0.8 \%$. Roberts et al. [4] states that Planaxis sulcatus is commonly found in mangroves. At station I not found mangrove plant, therefore allegedly Planaxis sulcatus is only found in this area: 


\section{Oceanography \& Fisheries Open access Journal}

Table 2: Density and Frequency of Mollusca at Station I.

\begin{tabular}{|c|c|c|c|c|}
\hline No & Mollusca & $\Sigma$ & Di (ind $/ 7 \mathrm{~m}^{2}$ ) & FR (\%) \\
\hline 1 & Cerithium baeticum & 3 & 3 & 3,1 \\
\hline 2 & Cerithiurn literatuns & 8 & 8 & 10,4 \\
\hline 3 & Cerithium obeliscus & 4 & 4 & 3,1 \\
\hline 4 & Cerithium thaanumi & 15 & 15 & 10,4 \\
\hline 5 & Cerithium $s p$ & 18 & 18 & 16,7 \\
\hline 6 & Cerithiopsis emersoni & 48 & 48 & 41,7 \\
\hline 7 & Cerithiopsis matara & 5 & 5 & 4,17 \\
\hline 8 & Clypeomorus brevis & 3 & 3 & 3,1 \\
\hline 9 & Clypeomorus corallium & 4 & 4 & 3,1 \\
\hline 10 & Anachis catenata & 1 & 1 & 0,8 \\
\hline 11 & Nassarius arcularius & 1 & 1 & 0,8 \\
\hline 12 & Neriiina meleagris & 1 & 1 & 0,8 \\
\hline 13 & Planaxis sulcatus & 1 & 1 & 0,8 \\
\hline \multirow[t]{2}{*}{14} & Gafrarium tumidum & 1 & 1 & 0,8 \\
\hline & Total number & 113 & 113 ind $/ 7 \mathrm{~m}^{2}$ & \\
\hline
\end{tabular}

\section{Station II}

Based on the analysis of the highest density data obtained on the species Cerithium thaanurni (13ind / $4 \mathrm{~m}^{2}$ ), this means that in an area of $4 \mathrm{~m}^{2}$ can be obtained 13 individuals Cerithium thaanumi and relative presence frequency Cerithium thaanumi by $43 \%$, this means the possibility of finding Cerithium thaanumi of all samples found in this area by $43 \%$ (Table 3). Environmental factors at station II that have been measured are sandy substrate type, sand clay and sandy clay, temperature range $27-30^{\circ} \mathrm{C}, \mathrm{pH}$ 8, salinity $30-32 \%$, and organic matter content ranged from
0.11 to $0.53 \%$, otherwise the station is a rocky area. Cerithiurn literatuns are found above the ground and many are also found behind rocks. Severns et al. [15] suggests that a small number of species from the Cerithiidae family favored sandy basin areas and on sand. Therefore Cerithium thaanumi is widely found in this area because this region has a substrate suitable for the life of Cerithium thaanumi. Cerithium thaanumi is not utilized by the inhabitants of Kemantren to be consumed, but the shells of Cerithium thaanumi can be used for handicrafts, so that they have economic value.

Table 3: Density and Frequency of Mollusca at Station II.

\begin{tabular}{|c|c|c|c|c|}
\hline No & Mollusca & $\Sigma$ & Di (ind/7 m²) & FR (\%) \\
\hline 1 & Cerithium baeticum & 2 & 2 & 6,4 \\
\hline 2 & Cerithium obeliscus & 2 & 2 & 6,4 \\
\hline 3 & Cerithium thaanumi & 13 & 13 & 43 \\
\hline 4 & Cerithiopsis matara & 1 & 1 & 3,2 \\
\hline 5 & Clypeomorus brevis & 1 & 1 & 3,2 \\
\hline 6 & Clypeomorus corallium & 5 & 5 & 17,2 \\
\hline 7 & Neritina $s p$ & 1 & 1 & 3,2 \\
\hline 8 & Urosalpinx perrugata & 1 & 1 & 3,2 \\
\hline 9 & Gafrarium turnidum & 3 & 3 & 10,7 \\
\hline \multirow[t]{2}{*}{10} & Chiton $s p^{2}$ & 1 & 1 & 3,2 \\
\hline & Total Number & 30 & 30 ind $/ 4 \mathrm{~m}^{2}$ & \\
\hline
\end{tabular}

The lowest density is found among other species of Clypeomorus brevis (1ind / $4 \mathrm{~m}^{2}$ ) this means that with an area of $4 \mathrm{~m}^{2}$ can be obtained by one individual Clypeomorus brevis and the relative presence of Clypeomorus brevis as large as 3.2\%, this means the possibility found Clypeomorus brevis of all samples obtained at $3.2 \%$. The station is located in front of the residential area, the type of sandy substrate, sand and sandy clay sandstone beside it is also rocky. Roberts et al. [4] states that Clypeomorus brevis can be found in the coral habitat. Clypeomorus brevis at this station can be found in small numbers, this is thought to be due to other factors such as competition, pre-integration or migration. 


\section{Station III}

Based on the results of data analysis, the highest density of Cerithiopsis emersoni (23ind $/ 4 \mathrm{~m}^{2}$ ) was obtained, which means that in $4 \mathrm{~m}^{2}$ area, 23 individuals of Cerithiopsis emersoni with relative emotional distress of Cerithiopsis emersoni were $21.3 \%$ the possibility of an emersoni cherry ebiopsis of all samples found in this area is $21.3 \%$. Station III is located in front of mangroves, sandy substrate type, temperature range $28-33{ }^{\circ} \mathrm{C}$, pH 8, salinity $25-30 \%$, and soil organic matter content ranges from 0.11 to $0.43 \%$. Cerithiopsis emersoni is a mollusk of the family of Cerithiidea which is often found on the surface of the substrate. Odum [16] states that the number of organisme, does not mean determine the structure komu itasitas in a region. Therefore Cerithiopsis emersoni cannot be said to be the most dominant organism in the coastal waters of Kemantren village. Cerithiopsis emersoni utilized by the coastal population of Kemantren for consumption. In order for Cerithiopsis emersoni in this area is not exhausted then Cerithiopsis emerionsi can be cultivated.

The lowest density is found in species such as Littorina irrorata $\left(1 \mathrm{ind} / 4 \mathrm{~m}^{2}\right)$, this means that in an area of $4 \mathrm{~m}^{2}$ we can obtain 1 individual Littorina irrorata with a relative presence frequency of $1.06 \%$, which means the possibility of finding Littorina irrorata of all samples found in this area is $1.06 \%$. Roberts et al. [4] states that the Littorinidae family is commonly found in tidal areas with hard substrate and mangroves. McNaughton \& Wolf [17], argue that organisms may compete if each tries to reach the best source along the quality gradient or if two individuals try to occupy the same place simultaneously. Therefore, the low density of Littorina irrorata in this area is thought to be due to commission, predation, or migration.

\section{Quadrant station grouping}

The result of data analysis using cluster-analysis of SPSS program based on substrate is made 3 cluster, that is cluster 1 , cluster 2, and cluster 3 . Each cluster is subdivided into several sub cluster and each sub cluster consists of several dendogram group. The cluster arrangement starts from cluster 2, then cluster 3 and the last cluster 1, this corresponds to the cluster's width on the dendogram. Each cluster categorizes the site (quadrant substrate) using molluscs. Cluster 2 is prepared by S2K 15, S2K29, covering station II (in front of residential area) and 3 (in mangrove). This cluster is prepared among others by Gafrarium tumidum. The environmental conditions in the cluster 2 area are the type of sandy substrate; temperatures ranging from $27-29^{\circ} \mathrm{C}$, salinity ranging from $25-32 \%, \mathrm{pH}$, and organic materials ranging from 0.4 to $0.5 \%$. Gafrarium tumidum includes molluscs of the bivalve class found in the substrate. According to Roberts et al. [4], Gafrarium tumidum can be found in areas with pore and muddy substrates. Gafrarium tumidum found in coastal waters of Kemantren Village lives by immersing itself in the substrate, so that the coast of Kemantren village is suitable for the life of Gafrarium tumidum. Gafrarium tumidum included in cluster 2 is caused because Gafrarium tumidum has the same living characteristics (environmental conditions) or similar to other molluscs that are in cluster 2 . The substrate type in this cluster is sandy but the content of organic material is high. Solid waste contains materials ororganic and inorganic materials. Due to the presence of waste of residents in the waters edge and the contribution of organic material from mangrove so that the content of organic material in cluster 2 is high (Table 3).

Cluster 3 prepared by S3KK1, S3K5, S3K14, is in the front area of mangroves. Cluster 3 is arranged among others by Planaxis sulcatus. The environmental conditions of the area are sandy substrates, temperatures ranging from $32-33{ }^{\circ} \mathrm{C}$, salinity $30 \%$. $\mathrm{pH} 8$, and organic materials ranging from 0.1 to $0.4 \%$. Planaxis sulcatus is a mollusc of the gastroperte class. During the study these molluscs were found on the surface of the soil and found in this area (front of mangroves). According to Roberts et al. [4], Planaxis sulcatus can be found in sandy clay habitat and mangrove areas. The location in front of the mangrove is a place that supports the life of Planaxis sulcatus. Planaxis sulcatus termasuk in cluster 3 is caused because these molluscs have characteristics (environmental conditions) that are similar to mollusks located in other clusters 3. According to Subarijanti [18], the materials in the waters come from the waters themselves (autochtonous) and come from outside or surrounding areas (allachtonous). Therefore, mangrove plantations contribute greatly to aquatic organisms, because mangrove leaves that fall into the waters will be utilized by organisme waters as foodstuffs (Table 4).

Table 4: Density and Frequency of Mollusca at Station III.

\begin{tabular}{|c|c|c|c|c|}
\hline No & Mollusca & $\boldsymbol{\Sigma}$ & Di (ind/7 $\mathbf{m}^{\mathbf{2}}$ ) & FR (\%) \\
\hline 1 & Cerithium baeticum & 3 & 3 & 3,2 \\
\hline 2 & Cerithium literatum & 9 & 9 & 9,6 \\
\hline 3 & Cerithium obeliscus & 1 & 1 & 1,06 \\
\hline 4 & Cerithium thaanumi & 11 & 23 & 10,6 \\
\hline 5 & Cerithiopsis emersoni & 23 & 8 & 21,3 \\
\hline 6 & Clypeomorus brevis & 8 & 1 & 8,5 \\
\hline 7 & Clypeomorus corallium & 1 & 1 & 1,06 \\
\hline 8 & Cerithiella whiteavesi & 1 & & 1,06 \\
\hline
\end{tabular}




\section{Oceanography \& Fisheries Open access Journal}

\begin{tabular}{|c|c|c|c|c|}
\hline 9 & Nerita polita & 2 & 2 & 2,1 \\
\hline 10 & Nassarius comptus & 2 & 2 & 2,1 \\
\hline 11 & Nassarius viticusis & 1 & 1 & 1,06 \\
\hline 12 & Nerztina meleagrzs & 5 & 5 & 5,3 \\
\hline 13 & Planaxis lineatus & 2 & 2 & 8,5 \\
\hline 14 & Planaxis sulcatus & 8 & 8 & 2,1 \\
\hline 15 & Littorina irrorata & 1 & 1 & 1,06 \\
\hline 16 & Strombus urceus & 2 & 2 & 2,1 \\
\hline 17 & Gafrarium tumidum & 7 & 7 & 7,4 \\
\hline 18 & Tagelus divisus & 1 & 1 & 1,06 \\
\hline 19 & Chiton spl & 2 & 2 & 2,1 \\
\hline 20 & Chiton sp2 & 2 & 2 & 2,1 \\
\hline 21 & Chiton sp3 & 1 & 1 & 1,06 \\
\hline \multirow[t]{2}{*}{22} & Chiton $s p 4$ & 5 & 5 & 5,3 \\
\hline & Total Number & 99 & 99ind $/ 4 \mathrm{~m}^{2}$ & \\
\hline
\end{tabular}

Cluster 1 is composed by S1K2, S1K5, S1K8, S1K11, S2K2, and S2K8, located at stations I and II which are areas near the estuary and in front of residential areas, composed by Cerithiopsis emersoni. The environmental conditions of the area are as follows the types of sandy substrates, sand clay and sandy clay, temperatures ranging from $28-30{ }^{\circ} \mathrm{C}$, salinity of $30-37 \%$, $\mathrm{pH}$ 8 , and organic materials ranging from 0.1 to $0.4 \%$. Cerithiapsis emersoni is a mollusk of the gastrophas class often found in station I, II, or III, found on the surface of the soil and in the rocks of the rocks. In addition to the residential area, station II is also close to the public cemetery, on the banks of the water can be found bamboo trees and frangipani trees, therefore the area (station II) shady. According to Roberts et al. [4] Cerithiidae is usually found in tidal dams, sandy substrate types and sandy patches. The coastal waters of Kemantren Village are a supportive area for the life of Cerithiopsis emersoni. Cerithiopsis emersoni is in cluster 1 , because this mosaic has the same characteristics (environmental conditions) with other molluscs in cluster 1. Organic material ranges from 0.1 to $0.4 \%$ with the type of sandy loamy substrate and sandy clay. According to Nybakken [11], beaches with finer sediments tend to accumulate soil organic matter larger than sand beaches, because the fine grains of sediment are very slow in draining water at low tide. Therefore, sandy loam clay and sandy clay can bind more organic material to sandy substrates. The organic material found in the substrate is utilized by mollusks as foodstuffs [19].

Species found not only in clusters include Gafrarium tumidum species found in clusters 1,2, and 3, Gafrarium tumidum can live in areas with sandy substrates, sand clay, and sandy clay. According to Roberts et al. [11], Gafra-fertil tumidum can live in sandy and clay habitats. The type of sandy substrate, sandy clay and sandy clay suitable for Gafrarium tumidum, because this species lives by immersing themselves. While species are found in one cluster, eg Nassarius arcularius in cluster 1 only, with sandy substrates, sand clay and sandy clay, temperatures ranging from $28-31{ }^{\circ} \mathrm{C}$, salinity ranges from $30-37 \%, \mathrm{pH}$, and organic materials range $0.1-0.4 \%$. Roberts et al. [4], Nassarius arcularius lives in a claysand habitat. Therefore, it is suspected that Nassurius arcularius can only live in areas with environmental conditions such as cluster 1 only. Cluster analysis with water management Based on cluster analysis result 3 clusters are cluster 1, 2 and cluster 3 Cluster 2 and 3 have similarity in the case of the sandy substrate type, the differences between the two clusters are thought to be due to other ecological factors (commission, predation, and migration $(*)$ ) that affect the presence of molluscs in these clusters. Cluster 1 is different from clusters 2 and 3, i.e., in terms of substrate type.

The type of substrate on cluster 1 varies, ie sandy, sandy clay, and sandy clay. Cluster 2 is the cluster with the lowest diversity (13), is in S2 K15, S2K29 (in front of residential area) and S3K24 (in front of mangrove), while cluster 3 is the cluster with the highest divergence (17), located in S3K1, S3K5 and S3K14 (in front of mangroves) can be said that cluster 3 is the best cluster compared to other clusters. Musus found during the study consisted of 3 classes (Gastropoda, Pelecypoda, and Polyplacophora), 3 orders (Archaeogastropoda, Mesogastropoda, and Neogastropods), 19 species (Gastropoda), 2 species (Pelecypoda), and 4 species (Polyplacophora). Roberts et al. (1982), the molluscs found in Jakarta Bay and Thousand Islands consist of 4 classes (Gastropoda, Pelecypoda, Polyplacophora, Scaphopoda), 3 orders (Archaeogastropoda, Mesogastropoda, and Neogastropoda), 275 species (Gastropoda), 95 species (Pelecypoda), 1 species (Polyplacophora), 2 spesies (Scaphopoda). The small number of mollusks found in the coastal area of Kemantren Village can be caused by several factors, among others, due to the difference in the number of quadrants taken $\left({ }^{*}\right)$. The result of cluster analysis in this study can be used as a material for rearranging the location for the interests of coastal management. This is because 
the coastal Village Kemantren experiencing the threat of coastal damage, among others with the discharge of oil in the waters and the disposal of garbage residents on the edge of the waters.

\section{Conclusion and Suggestions}

\section{Conclusion}

Based on the research results obtained; The identification of mollusc obtained 3 classes of Gastoda, Pelecypoda and Polyplachopora, 3 orders, and 238 taxa. During the study we found 22 taxa representing the order Archaeogastropoda, Mesogastropoda, and Neogastropoda, and 2 classes Pelecypoda and Polyplacophora. The lowest taxa number (3) is found in station code 30-31 (SIIK2), located in front of residential area while the highest taxa number 34 is located at station code 45 54 (SIIIK 1), located in front of mangrove. (1 individual), among others, of the Nassarius viticusis species, found at station I (K2 and K8) station codes 1-5 and 12-16, station II (K2 and K15) of station codes 30-31 and 36-39 and station III (K1, K5, and K24) station codes 45-54,55-63, and 69-77. The largest number of individuals (27 individuals) was Cerithiopsis emersoni, found at station I, quadrant 27, station code 28-29.

The lowest density among others was found in Planaxis sulcatus species (1ind $/ 7 \mathrm{~m}^{2}$ ) with a presence frequency of $0.8 \%$. Based on data analysis on station I, Cerithiopsis emersoni species has the highest density of $48 \mathrm{ind} / 7 \mathrm{~m}^{2}$ and relative frequency is $41,7 \%$. Data analysis at station II highest density is obtained at Cerithium thaanumi species (13ind $/ 4 \mathrm{~m}^{2}$ ) and attendance frequency $43 \%$, the lowest ability was obtained among other species of Neritina sp (1ind / $4 \mathrm{~m} 2$ ) and relative frequency $3.2 \%$. Data analysis at station III obtained the highest density on species of Emericon Cerithiopsis (23ind $/ 4 \mathrm{~m}^{2}$ ) with frequency $21.3 \%$, low density obtained in species such as Littorina irrorata (1ind $/ 4 \mathrm{~m}^{2}$ ) with frequency $1.06 \%$. Condition environments in coastal waters Kemantren village is sandy substrate, sand laminated, and sandy clay at station I and Il, and sandy type at station III, temperature range $27-33^{\circ} \mathrm{C}, \mathrm{pH} 8$, salinity $25-37 \%$ and organic material content ranged from $0.11-0.53 \%$. Data analysis using Cluster analysis program obtained 3 clusters, namely cluster 1 , cluster 2 , and cluster 3 . Each cluster is divided into sub cluster and each sub. The cluster consists of several groups of dendograms. Each cluster classifies quadrant stations using molluscs.

\section{Suggestion}

From the research results suggested:

a. Substrate diversity (e.g. rocky substrates) in mollusc sampling should be considered.

b. Need to study other ecological parameters (ocean currents, sedimentation, predation, competition, and migration).

c. Need to take advantage of other macrozoobenthos in location grouping. d. Need to study the cultivation problem of molluscs (Cerithiopsis emersoni).

e. Require the management of coastal areas of Kemantren Village with environmental insight, for example mangrove cutting, mangrove planting, reducing oil and garbage disposal at the waters edge, and making final waste dumps for waste.

\section{References}

1. Hendriks, D dan Rusmintardi (2000) Inventarisasi Jenis-jenis Moluska Di Perairan Teluk Lampung. Warta Puslitbang Oseanologi, Pusat Penelitian Dan Pengembangan Oseanologi Lembaga Ilmu Pengetahuan, Jakarta, Indonesia.

2. Arfiati D (2003) Peranan Dan Potensi Sumberdaya Pelecypoda. Universitas Brawijaya Program Pasca Sarjana. Tidak dipublikasikan, Malang, Indonesia.

3. Dharma B (1992) Siput dan Kerang Indonesia. Indonesian Shell II. Verlag Christa Hemmen. Federal Republic of Germany Distributor di Indonesia PT Sarana Graha.

4. Roberts D, Soemodihardjo S, Kastoro W (1982) Shallow Water Marine Mollusca of North-West Java. Lembaga Oseanologi Nasional, Lembaga Ilmu Pengetahuan, Jakarta, Indonesia.

5. Morris PA (1966) A Field Guide to Shells of the Pacific Coast and Hawaii. Houghton Mifflin Company Boston, USA.

6. Morris PA (1975) A Field Guide to Shell of the Antlantic and Gulf Coast and The West Indies. Houghton Mifflin Company Boston, USA.

7. Soegianto A (1994) Ekologi Kuantitatif Metode Analisis Populasi Dan Komunitas. Penerbit Usaha Nasional, Surabaya, Indonesia.

8. Santoso S (2002) SPSS Statistik Multivariat. PT Elex Media Komputindo, Jakarta, Indonesia.

9. Mardia KV, Kent JT, Bibby JM (1979) Multivariate Analysis. Academic Press, London, UK.

10. Romimohtarto dan, Juwana S (2001) Biologi Laut Ilmu Pengetahuan Tentang Biota Laut. In: Jilid II (Ed.), Penerbit Djambatan, Jakarta, Indonesia.

11. Nybakken (1988) Biologi Laut. Penerbit PT, Gramedia Pustaka Utama, Jakarta, Indonesia.

12. Dahuri RJ, Rais SP, Ginting dan MJ Sitepu (1996) Pengelolaan Sumber Daya Wilayah Pesisir Pantai dan Lautan Secara Terpadu. PT Pradnya Paramita, Jakarta, Indonesia.

13. Salamet H (2000) Studi Komunitas Moluska Di Perairan Pantai desa Pesisir. In: Jawa T, Skripsi H (Ed.), Kabupaten Probolinggo, Fakultas Perikanan, Unibraw, Malang, Indonesia.

14. Hellawel (1986) Biological Indicators of Freshwater Pollution and Environmental Management. Elsevier Science Publisher, London, UK, England.

15. Severns PF, Severns M, Dyerly R (2000) Tropical Shell. Periplus Etition (HK) Ltd., Singapore.

16. Odum EP (1993) Dasar-dasar Ekologi. In: T dan Srigandono B (Ed.), Diterjemahkan oleh Samingan Edisi Ketiga. Gadjah Mada University Press, Yogyakarta, Indonesia.

17. McNaughton SJ, dan LL Wolf (1990) Ekologi Umum. In: S dan B Srigandono (Ed.), Diterjemahkan oleh Pringgoseputro, Edisi Kedua. Gadjah Mada University Press, Yogyakarta, Indonesia.

18. Subarijanti HU (2000) Ekologi Perairan, Fakultas Perikanan. Universitas Brawijaya, Malang, Indonesia. 
19. Sutini L (1988) Sampah Organik Dan Cara Pengolahannya. Jilid I.

This work is licensed under Creative Commons Attribution 4.0 Licens

DOI: 10.19080/OFOAJ.2018.06.555684
Universitas Brawijaya, Fakultas Perikanan, Malang, Indonesia.

Your next submission with Juniper Publishers will reach you the below assets

- Quality Editorial service

- Swift Peer Review

- Reprints availability

- E-prints Service

- Manuscript Podcast for convenient understanding

- Global attainment for your research

- Manuscript accessibility in different formats ( Pdf, E-pub, Full Text, Audio)

- Unceasing customer service

Track the below URL for one-step submission https://juniperpublishers.com/online-submission.php 